\title{
Identification of Aluminium Fractions in Serum Using the Techniques of High Performance Liquid Chromatography, Ultrafiltration and Zeeman Atomic Absorption Spectrometry ${ }^{1}$ )
}

\author{
Halina B. Röllin and Claudina M. C. A. Nogueira
}

Department of Biochemistry, National Centre for Occupational Health, Johannesburg, South Africa

Summary: In order to ascertain the distribution of aluminium in normal and occupationally exposed sera, sizeexclusion chromatography using two fractionation techniques was applied: gel filtration (Sephadex G-100 SF) and HPLC (TSK G4000 SW). For each of the techniques, protein profiles obtained for control and exposed sera did not differ and aluminium was found to be associated with the same fractions.

Ultrafiltration of sera using Centricon concentrators having a nominal cut-off of $M_{\mathrm{r}}=10000$ confirmed the presence of high molecular mass and ultrafiltrable low molecular mass aluminium complexes in serum.

Absolute quantitation and relative distribution of aluminium in the aforementioned complexes in original and spiked sera were determined using Zeeman atomic absorption spectrometry. It was found that the relative distribution of aluminium between high molecular mass and low molecular mass fractions was $79.1 \%$ and $19.6 \%$ in controls, compared to $91.3 \%$ and $8.7 \%$ in exposed sera, which is highly significant for both high molecular mass $(\mathrm{p}<0.026)$ and low molecular mass $(\mathrm{p}<0.004)$. After spiking both control and exposed sera with $400 \mu \mathrm{g} / 1$ of $\mathrm{Al}$, the distribution changed. The percentage of the aluminium bound to high molecular mass increased from $79.1 \%$ to $98.9 \%$ for controls, and from $91.3 \%$ to $98.4 \%$ for exposed sera, confirming the affinity of high molecular mass proteins, especially transferrin for aluminium. On the other hand, the percentage of aluminium bound to low molecular mass decreased after spiking to $1.12 \%$ for controls and to $1.6 \%$ for exposed sera. These differences were not statistically significant. This suggests that at high concentrations of total aluminium in serum, the percentage of the aluminium bound to the low molecular mass is lower but the absolute quantity of aluminium circulating as the low molecular mass complex is increased. This low molecular mass aluminium complex is thought to play an important role in intracellular accumulation of aluminium.

An analytical method is proposed for the speciation of aluminium in serum.

\section{Introduction}

Aluminium is considered to be a detrimental element to living systems. Studies with aluminium provide a very good example of how a detrimental metal ion can make use of the endogenous ligands, in its absorption, transport, and availability so as to finally exert its toxic effects on the target organs. Successful competition for the binding sites on different ligands, normally available to carry metal ions which have similar properties, will be the target of such an interaction. Aluminium has been found to have the potential to cause toxicity to the central nervous system, skeletal and haematopoietic systems. Its accumulation in humans can produce a number of disorders. Aluminium toxicity has mainly been asso-

\footnotetext{
1) Parts of this study were presented at the 36th Congress of the Federation of South African Societies of Pathology (FSASP), held at the Karos Kruger Lodge, Mpumalanga, South Africa, 29th June-3rd July 1996, and abstracted in the Conference Proceedings.
}

ciated with patients on long-term haemodialysis causing dialysis-related diseases such as vitamin D-resistant osteomalacia and dialysis encephalopathy $(1-3)$.

There is also evidence of toxic effects of aluminium in occupationally exposed subjects (4-5). This is an area of particular concern because chronic occupational exposure to aluminium is very common.

In contrast to haemodialysis patients with high aluminium loading where the serum aluminium concentration can be elevated, the concentrations of aluminium in serum of occupationally exposed subjects are usually well within the acceptable normal levels. Hence, the use of aluminium concentrations as an index of aluminium loading remains speculative (6-7).

Identification of metal ions and their binding fractions in biological fluids can elucidate some of the underlying mechanisms of excess or deficiency of metal ions, as well as their toxicity. Even though the mechanisms of metal toxicity are mostly not known, it has been pro- 
posed that toxic metal bioavailability, and hence toxicity, depends on the physiochemical form of the metal before it enters the body to be transported within biological fluids and tissues. Knowledge in this field is still very limited not only for aluminium but also for other metals, especially if inhalation is the route of exposure.

Speciation studies to elucidate the distribution of aluminium among the different serum components are therefore of particular importance. Experimental and computer simulation studies (8) indicate that both low molecular mass and high molecular mass ligands are involved in the transport and bioavailability of aluminium. Day et al. studied the gastrointestinal absorption of aluminium in humans under physiologically normal conditions of aluminium loading using the ${ }^{26} \mathrm{Al}$ tracer and high energy accelerator mass spectrometry (9). This technique is highly specialised and not easily accessible. The highest plasma concentration of ${ }^{26} \mathrm{Al}$ was found in the sample obtained 6 hours post-ingestion. Ninety five percent of the absorbed aluminium was associated with high molecular mass species in plasma, of which $80 \%$ represented aluminium bound to transferrin, $10 \%$ bound to albumin, and $5 \%$ bound to other high molecular mass species. The non-protein low molecular mass fraction was shown to contain the remaining $5 \%$ of aluminium.

Aluminium absorption is possibly facilitated by its affinity for the iron-transporting protein transferrin, the aluminium-transferrin complex being endocytosed by susceptible brain cells (10).

The binding of aluminium to transferrin and to other ligands was also investigated by Fatemi et al., who confirmed that aluminium can bind to transferrin (11). $F a$ temi et al. also showed that aluminium binds to transferrin with less affinity than $\mathrm{Fe}^{3+}(12)$. This may explain why aluminium is released from transferrin much faster than iron. This led to the suggestion that this binding may be important if $\mathrm{Al}^{3+}$ uptake into cells is largely a result of receptor-mediated endocytosis of the $\left(\mathrm{Al}^{3+}\right)_{2}$-transferrin-complex (13).

Research in this field is hindered by the complexity of the analytical determinations of aluminium in biological fluids. This complexity becomes even more pronounced if speciation studies are called for.

Several workers have investigated aluminium distribution in serum of normal and uraemic subjects using gel filtration chromatography and ultrafiltration techniques; the results published are very controversial and far from reaching a consensus.

Trapp used Sephadex G-200 and G-50 to identify aluminium bindings in serum and found that the major acceptors of aluminium added to serum in vitro were albumin and transferrin. No bindings by low molecular mass constituents were observed (14). Bertholf et al. used a cation exchange resin, chelex, to quantitatively study aluminium binding to human serum albumin and transferrin. Both albumin and transferrin were found to produce linear Scatchard plots of aluminium binding data over the aluminium and protein concentration ranges found in humans (15). Favarato et al. used TSKGel HW 55S for determining the distribution of aluminium in human serum from both normal and occupationally exposed subjects. They found aluminium to be bound in a stable complex form to a protein fraction which they called albindin (16).

Pérez Parajón et al. used two different ultrafiltration techniques to quantify ultrafiltrable aluminium fractions (17). By using a standard ultrafiltration method they found that the ultrafiltrable fraction of aluminium amounted to $20.8-47.9 \%$ of the total concentration of aluminium in normal serum, while the non-filtrable aluminium amounted to $91.7-99.2 \%$. This result indicates that there was a contamination problem. On the other hand, when using the ultramicrofiltration technique the ultrafiltrable aluminium amounted to only $8.3 \%$.

Van Ginkel et al. used the gel filtration technique and found that $23 \%$ of total aluminium co-eluted with citrate and only $21 \%$ was found in the transferrin peak (18). Their experiment did not confirm earlier reports by King et al. that the ultrafiltrable aluminium fraction increased as the total serum aluminium concentration increased (19).

Recent studies by Wróbel et al., using ultramicrofiltration membranes, have shown that the natural relative distribution of ultrafiltrable aluminium in serum is a constant factor of $11 \%$ and this distribution does not seem to be influenced by the total serum aluminium concentration, the particular renal pathology of the patients, or even kidney transplantation (20).

Aluminium is an ubiquitous element and all procedures should be devised in such a manner as to eliminate or at least minimise and control the risk of external contamination. All procedures must be performed in a laboratory specialising in trace metal assays using very sensitive instrumentation. The detailed procedures to minimise contamination as described by Pérez Parajón et al., Van Landeghem et al. and Wróbel et al. are examples of correct analytical procedures employed to control contamination risk $(17,21,22)$.

The main objective of our study was to characterise the distribution of aluminium in serum of control and occupationally exposed subjects, following Sephadex G-100 SF and HPLC gel permeation profiling. Subjects were occupationally exposed to aluminium dust, by inhalation, in potrooms of a primary aluminium smelter.

In addition, we studied the speciation of aluminium between high molecular mass and low molecular mass serum fractions following ultrafiltration. 
Moreover, the Zeeman atomic absorption spectrometry technique was used to quantitate the aluminium present in high molecular mass and low molecular mass fractions in relation to total aluminium present in original and spiked serum.

\section{Materials and Methods}

\section{Size exclusion chromatography}

\section{Gel filtration using Sephadex}

Gel filtration of serum was performed on a Pharmacia column, 20 $\mathrm{mm}$ ID $\times 400 \mathrm{~mm}$ (Pharmacia Fine Chemicals, Uppsala, Sweden). The column was packed with Sephadex G-100 SF (Sigma Chemical Company No G-100-50) according to the manufacturer's specification.

The column eluent buffer was $0.1 \mathrm{~mol} / \mathrm{l}$ sodium dihydrogen phosphate, $0.2 \mathrm{~mol} / 1$ sodium chloride, $0.5 \mathrm{~g} / 1$ sodium azide (Analar, BDH Chemicals, Poole, England), adjusted to $\mathrm{pH} 7.4$ at $25^{\circ} \mathrm{C}$ and filtered through a GV $0.22 \mu \mathrm{m}$ membrane (Millipore No. GVWP04700). Flow rate was maintained with a peristaltic pump (LKB Bromma 12000 Varioperpex, 220V 50H). The eluent fractions were collected into aluminium-free polypropylene tubes (Sterilin \#144AS) using an automated fraction collector placed in a climate chamber at $4{ }^{\circ} \mathrm{C}$ (LKB Bromma 7000 Ultrorac).

\section{Calibration standards}

The column void volume $\left(\mathrm{V}_{\mathrm{o}}\right)$ was determined by using blue dextran 2000 (Pharmacia) and was found to be $9.5 \mathrm{ml}$ at a flow rate of $0.1 \mathrm{ml} / \mathrm{min}$. Calibration of the column was performed using either Pharmacia or Sigma (Sigma, St. Louis, MO, USA) standards, at a concentration of $0.010 \mathrm{~g} / \mathrm{l}$. Standards used were as follows: ribonuclease [relative molecular mass $\left(M_{\mathrm{r}}\right)=13500$ ], ovalbumin $\left(M_{\mathrm{r}}=45000\right)$, albumin $\left(M_{\mathrm{r}}=69000\right)$. A total of $0.5 \mathrm{mg}$ of each standard was loaded onto the column, representing a final loaded concentration of $1.5 \mathrm{mg}$ protein mixture.

\section{Serum specimens}

Sera were derived from blood drawn from occupationally exposed volunteers working in potrooms of a primary aluminium smelter. Control sera were obtained from subjects, none of whom had ever worked in the aluminium industry. Volunteers known to be using aluminium-containing medication were excluded from the study.

Serum samples were diluted $1: 1$ with eluent buffer and filtered through a $0.8 \mu \mathrm{m}$ filter (Millex-PF Millipore). A serum volume of $0.5 \mathrm{ml}$ was applied to the gel bed and elution was performed at a flow rate of $0.1 \mathrm{ml} / \mathrm{min}$. After elution of the void volume, collection of the fractions was started. A total of 424 fractions of $1 \mathrm{ml}$ each were collected per run into polypropylene tubes at $4{ }^{\circ} \mathrm{C}$.

Fractions obtained from both the calibration and the serum elutions were read on a Beckman DU Series 70 spectrophotometer at a wavelength of $280 \mathrm{~nm}$ to identify the protein fractions.

The fractions from the serum elution were stored at $4{ }^{\circ} \mathrm{C}$ prior to concentration and analysis of aluminium content.

\section{High performance liquid chromatography (HPLC)}

A high performance liquid chromatography system was used. This consisted of a Spectra Physics-SP 8100 liquid chromatograph equipped with SP 8110 autosampler; HP 1040A diode-array detector with ChemStation Software (Hewlett Packard Company) and a LKB 2113 Redirac fraction collector.

Size exclusion chromatography was performed using the gel permeation column TSK G4000 SW, $7.5 \mathrm{~mm}$ ID $\times 600 \mathrm{~mm}$ (Tosohaas, Japan). The mobile phase was the same phosphate buffer used for the Sephadex gel filtration.

\section{Calibration standards}

Calibration of the column was performed using the following standards: blue dextran $\left(M_{\mathrm{r}}=2000000\right), \gamma$-globulin $\left(M_{\mathrm{r}}=150000\right)$, albumin $\left(M_{\mathrm{r}}=69000\right)$, ovalbumin $\left(M_{\mathrm{r}}=45000\right)$, trypsin inhibitor $\left(M_{\mathrm{r}}=24000\right)$, ribonuclease $\left(M_{\mathrm{r}}=13500\right)$, and tyrosine $\left(M_{\mathrm{r}}\right.$ $=180$ ), at a concentration of $0.005 \mathrm{~g} / \mathrm{l}$. The flow rate was 0.3 $\mathrm{ml} / \mathrm{min}$.

\section{Serum specimens}

Serum samples were filtered through a $0.8 \mu \mathrm{m}$ filter and various volumes $(50-200 \mu$ l) were loaded onto the column to obtain protein profiles. Thirty six fractions, of $1 \mathrm{ml}$ volume, were collected for each run. The total run time for a flow of $0.3 \mathrm{ml} / \mathrm{min}$ was 120 min. Fractions were stored at $4{ }^{\circ} \mathrm{C}$ until analysed.

\section{Ultrafiltration method}

For ultrafiltration, original control sera and sera from occupationally exposed probands were used. To establish the aluminium distribution in serum at high aluminium load, aliquots of control sera and sera from exposed subjects were spiked with aluminium by adding $400 \mu \mathrm{g} / \mathrm{l}$ of $\mathrm{Al}$ to each sample and incubated at $37^{\circ} \mathrm{C}$ for $45 \mathrm{~min}$ before the ultrafiltration procedure. The $1000 \mathrm{mg} / \mathrm{l} \mathrm{Al}$ standard in $0.1 \mathrm{~mol} / 1 \mathrm{HClO}_{4}$ (Hopkins and Williams Ltd., Essex, England) was used to prepare the working standard of $1 \mathrm{mg} / 1 \mathrm{Al}$ for spiking, which was adjusted to $\mathrm{pH} 7.4$ with sodium hydroxide solution prior to use.

Separation of serum into high molecular mass and low molecular mass fractions was performed using Centricon concentrators (Amicon Inc.) having a nominal cut-off of $M_{\mathrm{r}}=10000$.

Aliquots of serum $(1 \mathrm{ml})$ were centrifuged in a fixed-angle rotor (Sorvall RC-2B centrifuge) at $5000 \mathrm{~g}$-force for 1 hour at $4^{\circ} \mathrm{C}$. The retentates and filtrates obtained for each serum sample were analysed for aluminium content.

\section{Preconcentration of protein fractions}

Due to the low concentrations of aluminium present in serum following the fractionation, some of the protein fractions were preconcentrated using precipitation with ice-cold acetone before analysis.

\section{Atomic absorption spectroscopy}

A Perkin-Elmer Model 4100L atomic absorption spectrometer with Zeeman-Effect background correction equipped with a transversely heated graphite atomizer was used for the determination of aluminium in serum, eluent, and protein retentates and filtrates after ultrafiltration.

The instrument settings and furnace programmes for analysis of aluminium in serum have been described previously (7). Our conditions differ from those published by Bradley and Leung, particularly in the drying and ashing stages, both for temperatures and times used (23). We used multiple drying stages and extended drying times to ensure the complete drying of the specimen prior to the ashing steps.

A calibration curve was constructed by the method of addition and was found to be linear up to $64 \mu \mathrm{g} / \mathrm{l}$ of $\mathrm{Al}$. Samples and standards were diluted with magnesium matrix modifier $(5.46 \mathrm{mmol} / \mathrm{l}$ $\mathrm{Mg}\left(\mathrm{NO}_{3}\right)_{2}$ in $1 \mathrm{~g} / 1$ Triton X-100) using the AS-70 autosampler on the spectrophotometer. For the determination of aluminium in the eluent, and protein retentates and filtrates, the procedure was modified to compensate for the matrix changes due to the presence of buffers. We found that to obtain optimal atomization, the temperature at the second stage of ashing had to be increased to $2000^{\circ} \mathrm{C}$, as opposed to $1400^{\circ} \mathrm{C}$, for serum.

\section{Quality control}

Accuracy of analysis was assessed by including quality control samples from Nycomed Seronorm ${ }^{\mathrm{TM}}$ Trace Elements (Oslo, Nor- 
way, batch 108) with each batch analysed. In addition, European Pharmacopoeia Commission BRP human albumin was analysed periodically.

\section{Contamination precautions}

To obtain reliable data throughout the entire study extremely stringent precautions were applied at all stages of sample manipulation. These were:

a) use of ultrapure water (Millipore $>16 \mathrm{M} \Omega \cdot \mathrm{cm}$ resistivity) for all dilutions and washing procedures,

b) use of high-purity chemicals,

c) use of polypropylene vessels and tubes,

d) soaking of all the containers in $50 \%$ nitric acid, overnight,

e) continuous screening of all materials and reagents for possible sources of metal contamination,

f) equilibrating of columns until aluminium free.

Blank readings were performed with each individual preparation. In addition, all preparations were performed in a laminar flow Class 1 cabinet and analysed under clean-room conditions.

\section{Statistics}

The ANOVA test was used for normally distributed data. The Kruskal-Wallis test (Mann-Whitney or Wilcoxon two sample test) was used for non-parametric data.

\section{Results}

Serum protein and aluminium profile following Sephadex G-100 SF gel filtration

The elution pattern of all sera on the Sephadex G-100 SF showed nine major reproducible peaks. The first aluminium peak co-eluted with protein in fractions 12 to $23\left(M_{\mathrm{r}}\right.$ between 100000 and 69000$)$. The next fraction with detectable aluminium, but no protein, was fraction 68. The next major aluminium peaks eluted in fractions 382 to $424\left(M_{\mathrm{r}}\right.$ less than 10000$)$ (fig. 1). All other de-

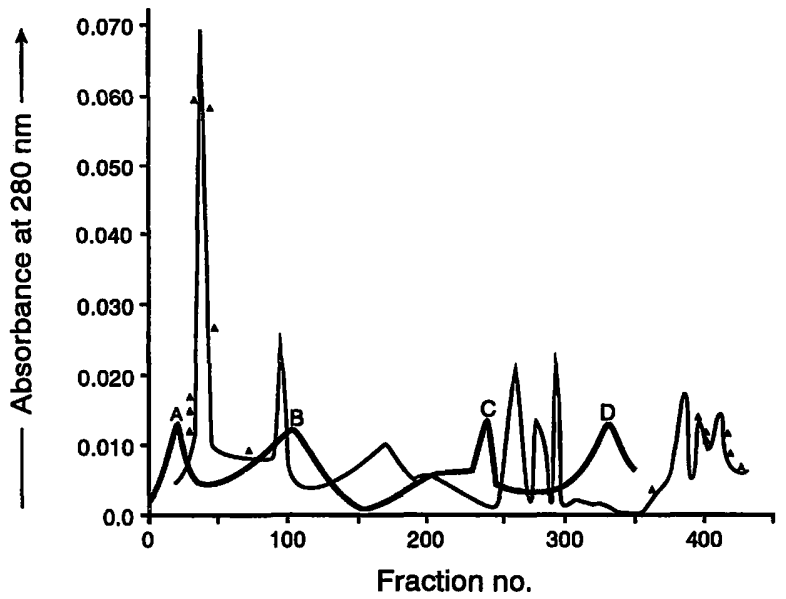

Fig. 1 Serum protein and aluminium profile following Sephadex G-100 SF gel filtration.

- Protein markers: $\mathrm{A}=$ blue dextran; $\mathrm{B}=$ albumin; $\mathrm{C}=$ ovalbumin; $\mathrm{D}=$ ribonuclease

- Serum profile

- Aluminium.
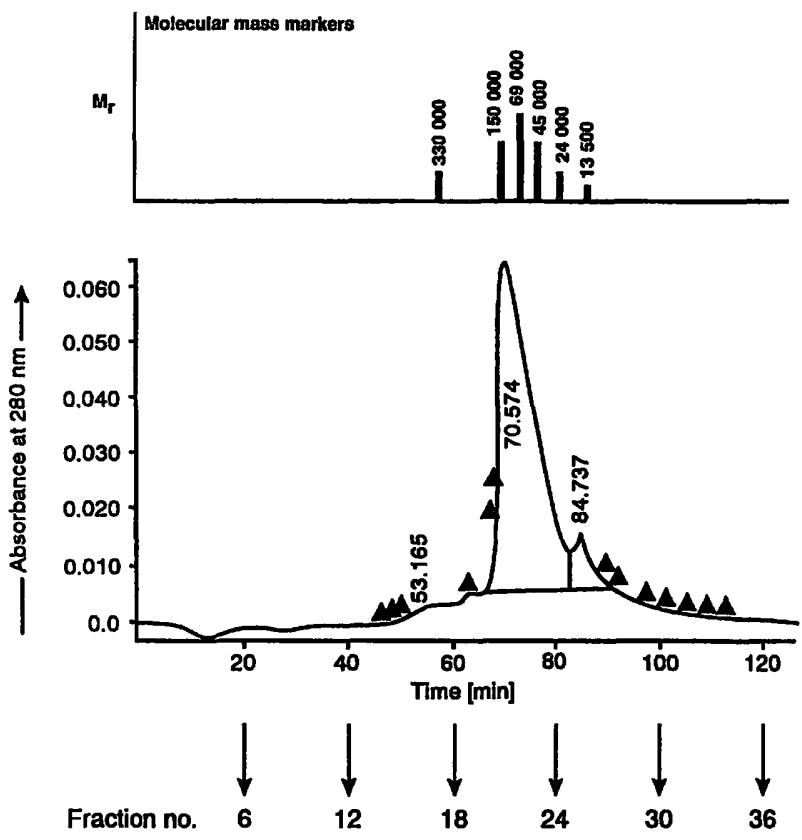

Fig. 2 Serum protein and aluminium profile following HPLC.

A Aluminium

$M_{\mathrm{r}} \quad$ Molecular mass markers.

tected serum protein peaks did not contain detectable aluminium, even after preconcentration of fractions.

\section{Serum protein and aluminium profile following HPLC}

In order to preserve the natural distribution of aluminium in serum, $0.1 \mathrm{~mol} / 1$ phosphate buffer, $\mathrm{pH} 7.4$ was used as the mobile phase. As a result, the elution peaks obtained are tailed, indicating that the conditions used were not optimal (fig. 2).

The elution profiles obtained did not differ for normal, exposed and spiked sera. The presence of aluminium was detected in fractions 13 to 15 , followed by fractions 18 to 21 . The ultrafiltrable aluminium complex was detected in fractions 26 to 35 .

\section{Ultrafiltration}

\section{HPLC serum profile following ultrafiltration}

The same serum samples (control and exposed) which were fractionated using the HPLC technique were submitted to ultrafiltration, after which both retentate and filtrate fractions obtained were re-fractionated using HPLC (fig. 3). The peaks obtained for the retentates and filtrates were found to be clearly defined, with the elution times corresponding to those obtained for the initial sera, prior to ultrafiltration.

\section{Distribution of aluminium $(\mu g / l)$ in serum following ultrafiltration}

Absolute quantitation of aluminium using the Zeeman atomic absorption spectrometry technique was per- 


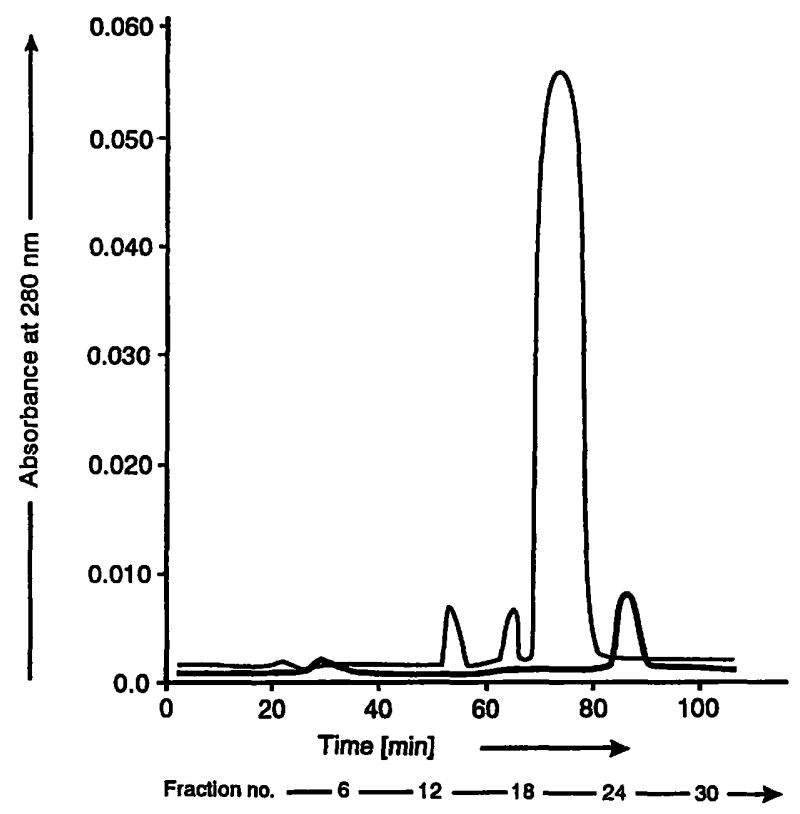

Fig. 3 HPLC serum profile following ultrafiltration.

- Retentate $\left(M_{\mathrm{r}}>10000\right)$

Filtrate $\left(M_{\mathrm{r}}<10000\right)$.

formed throughout the experimental procedure. The results presented in table 1 are a summary of a number of different experiments. The total aluminium in all serum samples was quantitated prior to the procedure of ultrafiltration. Given that the average aluminium concentrations in control serum samples are very low (4.76 $\pm 1.63 \mu \mathrm{g} / \mathrm{l}$ ), the concentrations of aluminium following ultrafiltration would be difficult to quantitate accurately
(7). For this reason control serum samples with the highest aluminium concentrations were chosen in this experiment; the fact that the aluminium concentrations in the control sera are higher than those in the exposed sera should not be given a clinical interpretation. Throughout all experiments the recovery obtained after ultrafiltration was good; in all cases the volume ratios of filtrates to retentates were approximately $2: 1$. Additional serum samples, from both control and exposed subjects, were spiked with aluminium to confirm the trend in the aluminium distribution.

Figure 4 shows the proportional aluminium binding to high molecular mass and low molecular mass serum moieties, for original and spiked sera. For the purposes of statistical analysis, the proportional aluminium binding is expressed also as a percentage of the total serum aluminium.

\section{Discussion}

In order to ascertain the distribution of aluminium in normal and occupationally exposed sera we applied two different size exclusion chromatographic techniques and an ultrafiltration method.

Care was taken to maintain the physiological conditions of sera by performing elutions at $\mathrm{pH} 7.4$ using a phosphate buffer. Profiling of sera on Sephadex G-100 SF ensured that the high molecular mass proteins with $M_{\mathrm{r}}$ $>100000$ were eluted in the void volume. The remain-

Tab. 1 Distribution of aluminium $(\mu \mathrm{g} / \mathrm{l})$ in serum following ultrafiltration.

\begin{tabular}{|c|c|c|c|c|c|}
\hline Sera from & $\begin{array}{l}\text { Total } \\
\text { aluminium }\end{array}$ & $\begin{array}{l}\text { Bound as } \\
\text { low molecular } \\
\text { mass complexes } \\
M_{\mathrm{r}}<10000\end{array}$ & $\begin{array}{l}\text { Bound as } \\
\text { high molecular } \\
\text { mass complexes } \\
M_{\mathrm{r}}>10000\end{array}$ & Sum & $\begin{array}{l}\text { Recovery } \\
(\%)\end{array}$ \\
\hline $\begin{array}{l}\text { Control subjects } \\
(\mathrm{n}=3)\end{array}$ & $\begin{array}{l}14.33 \\
14.15 \\
10.38\end{array}$ & $\begin{array}{l}2.34 \\
2.80 \\
2.43\end{array}$ & $\begin{array}{r}12.15 \\
12.00 \\
7.40\end{array}$ & $\begin{array}{r}14.49 \\
14.80 \\
9.83\end{array}$ & $\begin{array}{l}101.12 \\
104.59 \\
94.70 \\
100.14 \pm 5.0\end{array}$ \\
\hline $\begin{array}{l}\text { Exposed subjects } \\
(\mathrm{n}=3)\end{array}$ & $\begin{array}{r}10.19 \\
8.64 \\
8.21\end{array}$ & $\begin{array}{l}1.40 \\
0.85 \\
0.54\end{array}$ & $\begin{array}{r}10.00 \\
10.50 \\
8.10\end{array}$ & $\begin{array}{r}11.40 \\
11.35 \\
8.64\end{array}$ & $\begin{array}{l}111.87 \\
131.37 \\
105.24 \\
116.16 \pm 13.6\end{array}$ \\
\hline $\begin{array}{l}\text { Control subjects, spiked } \\
(n=4)\end{array}$ & $\begin{array}{l}413.30 \\
386.10 \\
386.55 \\
382.00^{*}\end{array}$ & $\begin{array}{l}4.95 \\
5.16 \\
3.60 \\
3.10\end{array}$ & $\begin{array}{l}333.20 \\
360.00 \\
407.00 \\
429.60\end{array}$ & $\begin{array}{l}338.15 \\
365.16 \\
410.60 \\
432.70\end{array}$ & $\begin{array}{r}81.82 \\
94.58 \\
106.22 \\
113.30 \\
98.98 \pm 13.8\end{array}$ \\
\hline $\begin{array}{l}\text { Exposed subjects, spiked } \\
(\mathrm{n}=5)\end{array}$ & $\begin{array}{l}438.30 \\
416.50 \\
413.20 \\
407.42^{*} \\
405.87^{*}\end{array}$ & $\begin{array}{l}5.27 \\
4.41 \\
8.84 \\
9.24 \\
6.10\end{array}$ & $\begin{array}{l}425.69 \\
394.32 \\
405.32 \\
396.23 \\
420.23\end{array}$ & $\begin{array}{l}430.96 \\
398.73 \\
414.16 \\
405.47 \\
426.33\end{array}$ & $\begin{array}{l}98.33 \\
95.73 \\
100.23 \\
99.52 \\
105.04 \\
99.77 \pm 3.4\end{array}$ \\
\hline
\end{tabular}

\footnotetext{
* Additional serum samples, from both control and exposed subjects, were spiked with aluminium to confirm the trend in aluminium distribution.
} 


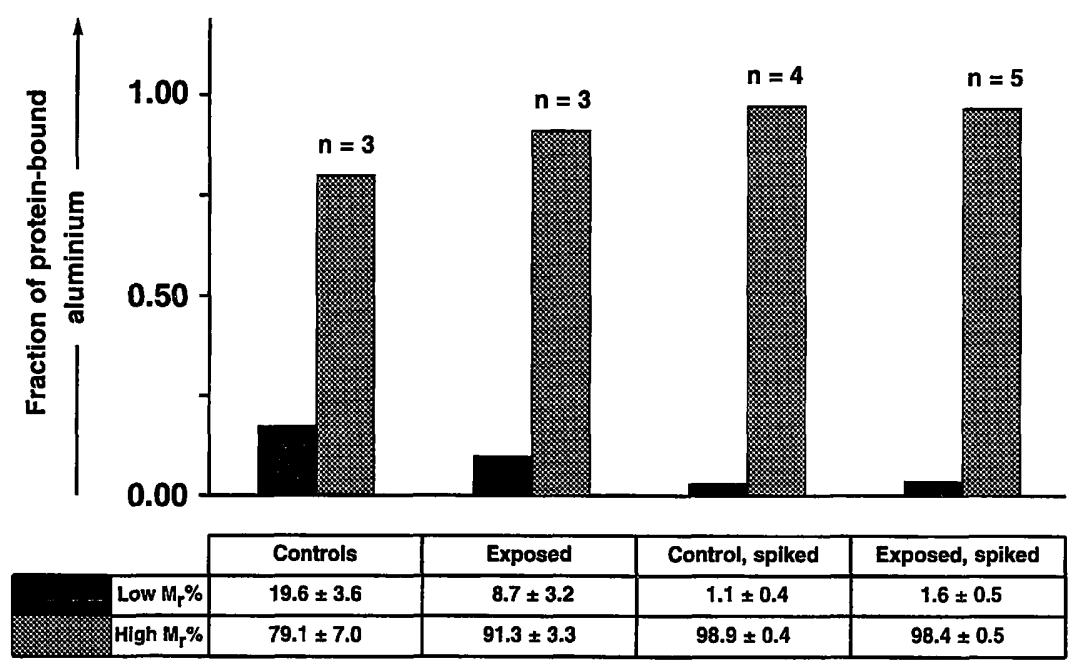

Fig. 4 Proportional aluminium binding to high and low $M_{\mathrm{r}}$ ligands in serum fractions. The differences between original sera from control subjects and exposed subjects were significant for both low $M_{\mathrm{r}}(\mathrm{p}<0.004)$ and high $M_{\mathrm{r}}(\mathrm{p}<0.026)$ fractions. After spiking, the differences in aluminium distribution were not statistically significant.

ing serum components were subsequently separated into nine distinctive peaks.

Detection of aluminium in all collected fractions revealed that aluminium co-eluted with the protein peak in fractions 12 to 23 , which corresponds to proteins with $M_{\mathrm{r}}<100000$ but $>69000$. We deduced that these fractions contained mainly transferrin-aluminium complexes. Aluminium was also detected in fraction 68 which eluted shortly before the corresponding albumin peak of the calibration standards. Until fraction 382 no aluminium was detected. Once the retention time reached the components with $M_{\mathrm{r}}<13500$, aluminium was again present in fractions 382 to 424 . The protein and aluminium profiles in serum obtained by this method are shown in figure 1. Although the separation of serum components was very satisfactory and the profiles obtained were reproducible using this technique, the procedure was tedious and time consuming.

An HPLC system equipped with a size exclusion TSK column was subsequently used to separate serum components. Separation obtained by HPLC was less than ideal. The eluent used was a phosphate buffer at $\mathrm{pH} 7.4$ to mimick physiological conditions and to minimise any artificial changes in the distribution of aluminium among serum components. Hence, optimal conditions of separation were not achieved.

A typical profile obtained by this method is shown in figure 2. Aluminium co-eluted in fractions 13 to 15 and 18 to 21 , representing high molecular mass serum proteins, and fraction 26 to 35 representing ultrafiltrable low molecular mass serum components, not necessarily proteins. Reproducible elution profiles were obtained for repeated sample injections and as in the Sephadex sepa-
Low $M_{\mathrm{r}} \%$ (High $\left.M_{\mathrm{r}} \%\right)=$ percentage of Al bound as low (high) molecular mass complexes.

Controls $=$ sera from control subjects.

Exposed $=$ sera from Al-exposed subjects.

rations, these profiles did not differ for the different sera analysed. This is in agreement with Favarato et al., who profiled sera from normal and exposed subjects, and found no differences in their protein profiles (24). Furthermore, in our experiments with the Sephadex and TSK columns, we observed no binding of aluminium to the respective gel matrices. In all the profiles, aluminium was only detected in the aforementioned protein fractions, and these results were reproducible for a number of different elutions.

To obtain a more accurate molecular mass speciation, we subjected the same sera to ultrafiltration by using Centricon concentrators having nominal cut-offs of $M_{\mathrm{r}}$ $=10000$. Figure 3 shows a typical profile with clearly defined peaks for retentate and filtrate following HPLC. In all cases, the elution times for these fractions corresponded to those obtained for the initial non-ultrafiltrated sera.

The distribution of aluminium between high molecular mass and low molecular mass serum fractions in relation to the total amount of aluminium present in different original and spiked sera was also investigated. In the spiking procedure we took extreme care to avoid disturbing equilibria: the $\mathrm{pH}$ of the aluminium standard solution was adjusted to $\mathrm{pH} 7.4$ using a sodium hydroxide solution and the standard was prepared daily and filtered through $0.22 \mu \mathrm{m}$ membranes before use. The "background" aluminium was carefully monitored and subtracted from all the readings.

The total aluminium was quantitated prior to the procedure of ultrafiltration. Following ultrafiltration, the recovery for the sum of high molecular mass and low molecular mass fractions was calculated. The average re- 
covery for control sera, before and after spiking, was $100.14 \pm 5.0 \%$ and $98.98 \pm 13.8 \%$, respectively. The average recovery for sera from exposed subjects, before and after spiking, was $116.16 \pm 13.6 \%$ and 99.7 $\pm 3.4 \%$, respectively. The overall mean recovery was $102.91 \pm 11.0 \%$, which is very satisfactory.

Speciation of aluminium between high molecular mass and low molecular mass serum fractions after ultrafiltration, expressed as a percentage of the total aluminium present in the original serum, showed that in controls, $19.6 \pm 3.6 \%$ of aluminium was bound to low molecular mass fractions with the remaining $79.1 \pm 7.0 \%$ binding to high molecular mass fractions. In serum of exposed workers this distribution differed, with only $8.7 \pm 3.2 \%$ binding to low molecular mass fractions and 91.3 $\pm 3.3 \%$ to high molecular mass fractions. The differences between control and exposed sera were found to be significant for both low molecular mass $(p<0.004)$ and high molecular mass $(\mathrm{p}<0.026)$. After spiking control and exposed sera with $400 \mu \mathrm{g} / \mathrm{l}$ of $\mathrm{Al}$, this distribution changed noticeably. In the case of control sera, only $1.12 \pm 0.4 \%$ of aluminium was bound to low molecular mass fractions and $98.88 \pm 0.4 \%$ bound to high molecular mass fractions. In exposed sera, $1.6 \pm 0.5 \%$ was bound to low molecular mass fractions, with the remaining $98.4 \pm 0.5 \%$ binding to high molecular mass protein complexes. These changes in aluminium distribution were found to be not significant due to the small sample size and the difference in variance between the two samples. This redistribution of aluminium in serum, when the aluminium concentration is high, is comparable to that observed by Favarato et al. (24).

Our results are in direct conflict with those obtained by Wróbel et al., who found that the percentage of ultrafiltrable aluminium did not change with increasing concentration of aluminium. They found that, when the total aluminium increased, the aluminium content bound to the low molecular mass fraction increased in the same proportion (20). In our study, it appears that the percentage of low molecular mass aluminium complexes decreased with an increase in total aluminium content. These differences may be attributed to the different cutoff membranes used in both studies $\left(M_{\mathrm{r}}=30000\right.$ used in the former). On the other hand, in our study, the absolute quantity of aluminium available for circulation, in spiked sera, was much higher than that found in original serum samples. Furthermore, in our study we used sera from healthy occupationally exposed subjects, as opposed to uraemic subjects.

We obtained acceptable separation of serum components and identification of aluminium binding sites by two size exclusion chromatographic methods. The profiles obtained for all the sera analysed were very similar and no displacement of aluminium between different fractions was observed. In addition, there was no transfer of aluminium between serum samples and column packing materials. Background contamination levels for eluent and column matrices were controlled and minimised by following the procedures described previously in the methodology section. Spiking of the sera with $400 \mu \mathrm{g} / \mathrm{l}$ of $\mathrm{Al}$ at a controlled $\mathrm{pH}$ did not produce saturation effects and aluminium was detected only in specific fractions. Prior to deciding on the concentration of aluminium to be used in the spiking experiments, we worked with serum samples obtained from uraemic patients, containing, on average, $390 \mu \mathrm{g} / \mathrm{l}$ of $\mathrm{Al}$.

The ultrafiltration technique proved to be the method of choice for the quantitative recovery studies, for both original and spiked sera, without dilution effects which are inherent to Sephadex and HPLC separations.

\section{Conclusion}

In our present study the distribution of aluminium between high molecular mass and low molecular mass serum complexes in original sera from exposed subjects differed from that observed in control sera. More aluminium was present in high molecular mass fractions in exposed subjects than in controls having similar total aluminium content. This confirms that high molecular mass proteins, transferrin being the main protein carrier of aluminium, have an ability to bind aluminium in blood. Initially, this binding of aluminium to transferrin may have detoxifying effects, though the final deposition of the aluminium remains the source of concern (25). After the addition of a high concentration of aluminium $(400 \mu \mathrm{g} / 1$ of $\mathrm{Al})$ to sera from occupationally exposed subjects, more aluminium was bound to high molecular mass fractions, with only $1.6 \%$ of aluminium being bound to the low molecular mass species. However, this aluminium percentage represents an increased absolute aluminium quantity in the circulation. This is of particular importance in the industrial setting, since ultrafiltrable aluminium complexes (fluoride, silicic acid and citrate) are thought to play a major role in the bioavailability and excretion of aluminium.

\section{Acknowledgements}

The authors acknowledge the cooperation of all the volunteers who took part in the study and Danuta Kielkowski from the National Centre for Occupational Health, Johannesburg, for statistical assistance. We thank Professor Nerina Savage from the Department of Medical Biochemistry, University of the Witwatersrand Medical School, Johannesburg, for valuable suggestions and reviewing the manuscript. 


\section{References}

1. Alfrey AC, LeGrende GR, Kaehny WD. The dialysis encephalopathy syndrome. Possible aluminium intoxication. N Engl J Med 1976; 294:184-8.

2. Wills MR, Savory J. Aluminium poisoning: dialysis encephalopathy, osteomalacia, and anaemia. Lancet 1983; II:29-34.

3. Crapper DR, Quittkat S, Krishnan SS, Dalton AJ, DeBoni U. Intranuclear aluminium content in Alzheimer's disease, dialysis encephalopathy, and experimental aluminium encephalopathy. Acta Neuropathol 1980; 54:19-24.

4. Rifat SL, Eastwood MR, Crapper McLachlan DR, Corey PN. Effect of exposure of miners to aluminium powder. Lancet $1990 ; 336: 1162-5$.

5. White DM, Longstreth WT Jr, Rosenstock L, Claypoole KHL, Brodkin CA, Towns BD. Neurological syndrome in 25 workers from an aluminium smelting plant. Arch Intern Med 1992; 152:1443-8

6. Gitelman HJ, Alderman FR, Kurs-Lasky M, Rockette HE. Serum and urinary levels of workers in the aluminium industry. Ann Occup Hyg 1995; 29:181-91.

7. Röllin HB, Theodorou P, Cantrell AC. Biological indicators of exposure to total and respirable aluminium dust fractions in a primary aluminium smelter. Occup Env Med 1996; 53:41721.

8. Venturini M, Berthon G. Aluminium speciation studies in biological fluids. Part 2. Quantitative investigation of aluminiumcitrate complexes and appraisal of their potential significance in vivo. J Inorg Biochem 1989; 37:69-90.

9. Day JP, Barker J, Evans LJA, Perks J, Seabright PJ, Acrill $\mathrm{P}$, et al. Aluminium absorption studied by ${ }^{26} \mathrm{Al}$ tracer. Lancet $1991 ; 337: 1345$.

10. Morris CM, Candy JM, Oakley AE, Taylor GA, Mountfort S, Bishop $\mathrm{H}$, et al. Comparison of the regional distribution of transferrin receptors and aluminium in the forebrain of chronic renal dialysis patients. J Neurol Sci 1989; 94:295.

11. Fatemi SJA, Kadir FHA, Moore GR. Aluminium transport in blood serum. Binding of aluminium by human transferrin in presence of human albumin and citrate. Biochem J 1991; 280:527-32.

12. Fatemi SJA, Williamson DJ, Moore GR. ${ }^{27} \mathrm{Al}$ NMR investigation of $\mathrm{Al}^{3+}$ binding to small carboxylic acids and the proteins albumin and transferrin. J Inorg Biochem 1992; 46:35-40.

13. Marques $H$. Kinetics of the release of aluminium from human serum dialuminium transferrin to citrate. J Inorg Biochem 1991; 41:187-93.

14. Trapp GA. Plasma aluminium is bound to transferrin. Life Sciences $1983 ; 33: 311-6$.
15. Bertholf RL, Wills MR, Savory J. Quantitative study of aluminium binding to human serum albumin and transferrin by a chelex competitive binding assay. Biochem Biophys Res Comm 1984; 125:1020-4.

16. Favarato M, Mizzen CA, McLachlan DR. Resolution of serum aluminium-binding proteins by size-exclusion chromatography: identification of a new carrier of aluminium in human serum. J Chromatogr 1992; 576:271-85.

17. Pérez Parajón J, Blanco González E, Cannata JB, Sanz Medel A. A critical appraisal of the speciation of aluminum by ultrafiltration. Trace Elem Med 1989; 6:41-6.

18. Van Ginkel MF, Van der Voet GB, Van Eijk HG, Wolff FA. Aluminium binding to serum constituents: a role for transferrin and for citrate. J Clin Chem Clin Biochem 1990; 28:459-63.

19. King SW, Savory J, Wills MR. Aluminium distribution in serum following haemodialysis. Ann Clin Lab Sci 1982; 12:143-9.

20. Wróbel K, Blanco González E, Sanz Medel A. Ultrafiltrable aluminium in normal and uraemic sera: influence of desferrioxamine therapy. Trace Elem Med 1993; 10:97-103.

21. Van Landeghem GF, D'Haese PC, Lamberts LV, De Broe ME. Quantitative HPLC/ETAAS hybrid method with an on-line metal scavenger for studying the protein binding and speciation of aluminium and iron. Anal Chem 1994; 66:216-22.

22. Wróbel K, Blanco González E, Wróbel K, Sanz Medel A. Aluminium and silicon speciation in human serum by ion-exchange high-performance liquid chromatography-electrothermal atomic absorption spectrometry and gel electrophoresis. Analyst 1995; 120:809-15.

23. Bradley C, Leung FY. Aluminium determined in plasma and urine by atomic absorption spectroscopy with a transversely heated graphite atomizer furnace. Clin Chem 1994; 40:431-4

24. Favarato M, Mizzen CA, Sutherland MK, Krishnan B, Kruck TPA, Crapper McLachlan DR. Aluminium-binding serum proteins: desferrioxamine alters serum aluminium speciation. Clin Chim Acta 1992; 207:41-55.

25. Martin RB. Aluminium speciation in biology. In: Wiley $\mathbf{J} \&$ Sons, editors. Aluminium in biology and medicine. Ciba Foundation Symposium 169, 1992:5-25.

\section{Received September 9, 1996/January 3, 1997}

Corresponding author: Dr. Halina B. Röllin, Department of Biochemistry, National Centre for Occupational Health, P.O. Box 4788, Johannesburg 2000, South Africa 